Associations of self-perceived competence, well-being and sense of belonging among pre- and in-service teachers encountering children with diverse needs

\title{
Nislin, Mari
}

2019-08-08

Nislin , M \& Pesonen , H 2019 , ' Associations of self-perceived competence, well-being and sense of belonging among pre- and in-service teachers encountering children with diverse needs ' , European Journal of Special Needs Education , vol. 34 , no. 4 , pp. 424-440 . https://doi.org/10.1080/08856

http://hdl.handle.net/10138/314208

https://doi.org/10.1080/08856257.2018.1533093

acceptedVersion

Downloaded from Helda, University of Helsinki institutional repository.

This is an electronic reprint of the original article.

This reprint may differ from the original in pagination and typographic detail.

Please cite the original version. 
Associations of self-perceived competence, well-being and sense of belonging among pre- and in-service teachers encountering children with diverse needs

Mari Nislina* and Henri Pesonen ${ }^{\mathrm{b}}$

aDepartment of Early Childhood Education, The Education University of Hong Kong, Hong Kong, Hong Kong SAR; 'Faculty of Educational Sciences, University of Helsinki, Helsinki, Finland

* Mari Nislin, Assistant Professor, Department of Early Childhood Education, The Education University of Hong Kong, 10 Lo Ping Road, New Territories, Tai Po, Hong Kong, manislin@eduhk.hk, +85257256656 


\section{Associations of self-perceived competence, well-being and sense of belonging among pre- and in-service teachers encountering children with diverse needs}

In this article, we sought to determine the extent to which pre- and in-service teachers' self-perceived competence is associated with sense of belonging and wellbeing during special education teacher studies, as well as determine whether there are differences among these factors between pre-service and in-service teachers. These are areas in which there is currently a shortage of research. Our data were collected using a survey with close-ended questions. The respondents consisted of 58 in-service and 29 pre-service teachers, aged 21-56 years. Data were analysed utilizing quantitative methods. The findings revealed that the respondents demonstrated generally high levels of engagement and low to moderate levels of burnout. The results further indicated that the respondents reported themselves to be most competent when dealing with children of drug-related family abuse and less competent in working with children with severe disabilities. Although well-being and self-perceived competence were associated, we could not find any associations between these factors and the sense of belonging. Given the theoretical and empirical evidence, a deeper understanding of the factors relating to teachers' ability to encounter diverse needs is unquestionably needed. The key findings are discussed in detail, and practical implications for teacher education are given.

Keywords: Diverse needs; special education; sense of belonging; well-being; competence; inclusion; teacher education 


\section{Introduction}

There has been a strong shift towards more inclusive educational settings where children with diverse needs ${ }^{\mathrm{i}}$ and backgrounds $\mathrm{s}^{\mathrm{ii}}$ are placed in mainstream contexts (e.g. Ferguson 2008; Savolainen 2009; Pesonen et al. 2015). These inclusive settings can create a climate that supports a sense of belonging for all individuals (Pesonen 2016). For example, children and teachers can feel personally included, accepted and supported in the classroom and in the entire school community. Significantly, successful experiences of feeling accepted, which can lead to feelings of a strong sense of belonging, improve a person's overall well-being (Baumeister and Leary 1995). School teachers who have such competencies and values, including the belief that every child can succeed, support a sense of belonging for the adults (e.g. teachers and classroom assistants) as well as the children in the inclusive setting (Pesonen 2016). Yet teachers who work in an inclusive classroom without such characteristics and values may experience challenges in coping at work (Skaalvik and Skaalvik 2011). For instance, feelings of inadequacy and an inability to carry out their work in a meaningful way are rather common among teachers (Brouwers and Tomic 2000; Hakanen, Bakker, and Schaufeli 2006; Montgomery and Rupp 2005). Children's challenging behaviours, emotional and social problems, as well as potential adverse living conditions at home may be seen as demands causing strain for teachers who in turn are predisposed to a high risk of burnout (Bakker et al. 2004; Demerouti et al. 2001; Hakanen 2009; Buchanan 2010). Simultaneously, teachers' work can be highly motivating and inspiring, and its basic elements can contribute to satisfaction and well-being (Estola, Erkkilä, and Syrjälä 2003; Nislin 2016; Rantala and Määttä 2011).

The globally increasing numbers of inclusive settings require teachers to have the kinds of competencies that enable them to address the needs of all students (Paju et al. 2015). In Finland, a three-tier support model requires all teachers to identify a child's support needs as early as possible, based on the teachers' classroom observations of struggling students (Thuneberg et al. 2013). Furthermore, the ethos of Finnish educational policy emphasises neighbourhood school attendance for all children, which includes the ideological aim of preventing segregated school arrangements for those with special educational needs (Ahtiainen 2017). Owing to the shift towards more inclusive settings, teachers benefit from being able to reflect on their attitudes towards inclusion (Campbell, Gilmore, and Cuskelly, 2003). Reflection on attitudes consists of self-reflection to the extent that teachers consider 
themselves to be skilful and competent in teaching children with diverse needs (e.g. children with disabilities or severe mental health problems) or from various backgrounds (e.g. children who are maltreated or neglected) (Nislin et al. 2015). Positive values and a belief in inclusion, which in practice can appear as abilities to meet the needs of all children, can support a sense of belonging for both children and teachers in school contexts. For example, such attitudes towards inclusion might be visible as frequent, warm interactions with school colleagues and children, which in turn creates belongingness (Ma 2003; Prince and Hadwin 2012). In contrast, individuals (e.g. teachers) who constantly experience challenges in forming and maintaining relationships with others (e.g. teacher-student relationship) or have difficulty meeting their need to belong are likely to experience ill effects (e.g. depression) (Juvonen 2006; Prince and Hadwin 2012).

Teacher education thus plays a significant role in educating qualified and skilful future teachers, and specifically special education teachers, who have a philosophy that supports belonging in their professional working environments. It is highly important that, during the course of their studies, qualifying teachers master the skills and knowledge they will need in working life and develop a strong professional identity in order to take up the challenges that the profession will pose (Onnismaa, Tahkokallio, and Kalliala, 2015). Those competencies acquired during university studies help teachers adapt to their new work and prevent coping problems from arising (Klusmann et al. 2012), which in turn might have negative effects on their sense of belonging (Baumeister and Leary, 1995). Experiencing a strong sense of belonging during university studies, with warm relationships with other students and faculty, can protect student teachers' well-being (e.g. Freeman, Anderman, and Jensen 2007). For example, university studies can facilitate interactions among the students, as well as provide an opportunity to share and explore opinions, values, beliefs and identities. Moreover, this can shape their values about diverse learning needs, encouraging them to be more open and accepting. Such experiences of acceptance along with rewarding and positive relationships with fellow students can lead to positive relationships with other people later in life and to improved social outcomes (see e.g. Murray and Greenberg 2000).

To guarantee the best possible outcomes for graduating teachers, it is important to consider their overall well-being (which can be linked with a strong sense of belonging) already during their studies. Coping mechanisms during university study are predictors for early career work-related well-being (Salmela-Aro, Tolvanen, and Nurmi 2009). 


\section{Well-being, sense of belonging and self-perceived competence among pre-and in-service teachers}

In this study, we focus on well-being, sense of belonging and self-perceived competence among pre- and in-service teachers. In-service teachers already hold an education degree with a teacher qualification and are currently in a special education teacher qualification programme (60 ECTS). Pre-service teachers are degree students who are majoring either in early childhood education or special education.

Well-being is defined by the concepts of study burnout and study engagement in order to capture the dual nature of well-being (Hakanen 2009). Stress and burnout are commonly used terms to describe the coping problems caused by a mismatch between the demands and resources that individuals encounter in studying or working. Burnout is a serious and chronic state caused by prolonged coping problems, characterized by exhaustion, cynicism and decreased professional self-esteem (Maslach, Schaufeli, and Leiter 2001; Maslach 2003; Schaufeli, Leiter, and Maslach 2008). Engagement on the other hand is a positive antithesis to burnout, as study and work can encourage enthusiasm and motivation (Schaufeli and Bakker 2004) and can positively enhance well-being. Schaufeli et al. (2002, p. 74-75) define engagement as "a positive, fulfilling state of mind, that is characterized by vigor, dedication and absorption." This concept tries to capture the multidimensional nature of engagement, which involves aspects of behaviour (vigour), emotion (dedication) and cognition (absorption). Students with high levels of engagement are full of energy, show dedication to and involvement in their studies and are so immersed in their studies that time flies (Salanova et al. 2010; Schaufeli et al. 2002; Vasalampi et al. 2009).

Furthermore, a sense of belonging is a fundamental element linked to well-being (e.g. Baumeister and Leary 1995; Juvonen 2006). The role of a sense of belonging in pre- and inservice teachers' well-being is understudied, especially in relation to the associations between a sense of belonging and self-perceived competence. Sense of belonging is defined in the literature as the extent to which an individual feels included, respected, accepted and supported by others in a variety of different social contexts (Baumeister and Leary 1995; Hagerty et al. 1992). For example, during the years of university education or continuing qualification programs, students' feelings of self-acceptance and of acceptance by others create strong feelings of belonging. This in turn can increase overall well-being (Baumaister 
\& Leary 1995). Research further suggests that the lack of sense of belonging can lead to severe physical and psychological health problems, such as depression (Baumaister and Leary 1995; Juvonen 2006; Pesonen 2016).

We found numerous generic studies on university students' sense of belonging to the university community that also are positively related to overall physical and mental wellbeing (e.g. Freeman, Anderman, and Jensen 2010; Hoffman et al. 2002). Similarly, there are studies focusing on university students' well-being which demonstrate that academic performance is related to study engagement and burnout (e.g. Upadyaya and Salmela-Aro 2011; 2009). Furthermore, studies have shown that competence (e.g. self-efficacy, pedagogical knowledge) is associated with teachers well-being at work and job performance (Lauermann and König 2016; Klassen and Chiu 2010). In this study, the aim is not to explore the multidimensional structure of competence, but rather to capture pre- and in-service teachers' self-perceived and reported ability to work with children with diverse needs. In other words, this self-concept of ability is examined by asking the student teachers to identify their self-perceived competence to work with children with various needs and backgrounds.

We failed to locate any studies focusing on pre- and in-service teachers' self-perceived competence or the extent to which competence is linked to their sense of belonging and wellbeing. We expect that our findings are similar to earlier research in study engagement, burnout and sense of belonging (e.g. Juvonen 2006; Skaalvik and Skaalvik, 2011). To be more precise, we expect that experiences of sense of belonging are positively related to wellbeing. One purpose of our study is to determine whether a strong sense of belonging is associated with better well-being as well as with better self-perceived competence in dealing with children with diverse needs. Because there appears to be no previous research investigating those underlying mechanisms, specifically among and between pre- and inservice teachers, this study adds significantly to the existing literature.

\section{Research objectives:}

1. The first aim is to examine the connections between pre- and in-service teachers' burnout and engagement, their sense of belonging and their self-perceived competence in working with children of diverse needs and backgrounds (Figure 1). 
2. The second aim is to determine whether there are differences in well-being, sense of belonging and self-perceived competence between pre-service teachers and in-service teachers.

Figure 1. Theoretical model of the associations between sense of belonging, well-being and self-perceived competence

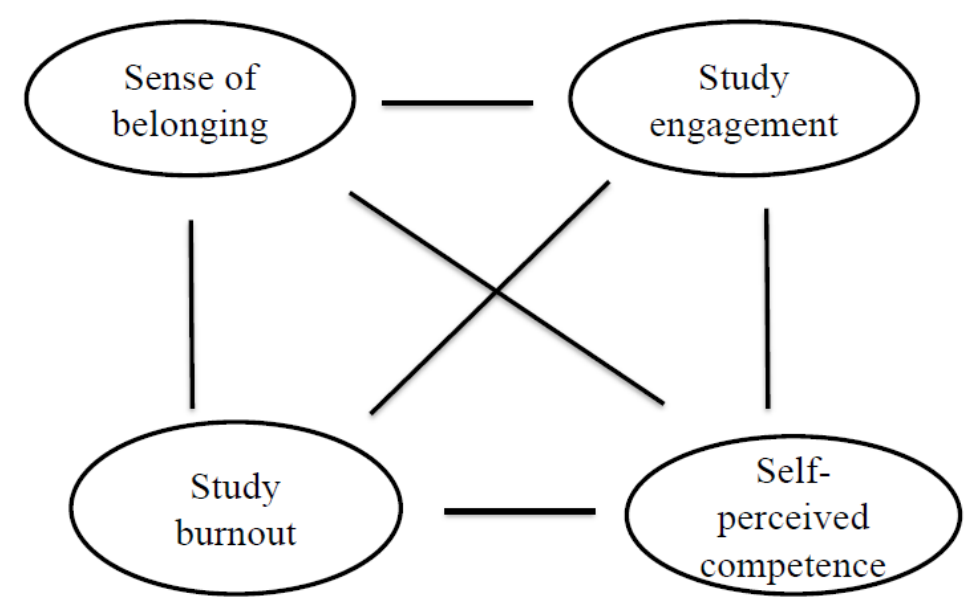

\section{Methods}

\section{Participants}

This study is part of an international comparative project conducted in Hong Kong and Finland in the years 2017-2018. Participants in this sub-study were from the University of Helsinki. The participant data were drawn from pre-service teachers in early childhood education and special education degree programmes and in-service teachers attending a special education qualification programme. There were 58 in-service and 29 pre-service teachers. Participants (female $n=76$, male $n=11)$ were 21-56 $(M=35,9, S D=9,97)$ years old. Students attending the special education qualification programme were in-service teachers (e.g. kindergarten, primary and secondary schools, vocational schools) who had already earned a master's or a bachelor's degree, with a minor in special education (25 credit points), teacher qualification studies and working experience in teaching. Demographics are presented in Table 1. 
Table 1. Demographic characteristics of the in- and pre-service teachers.

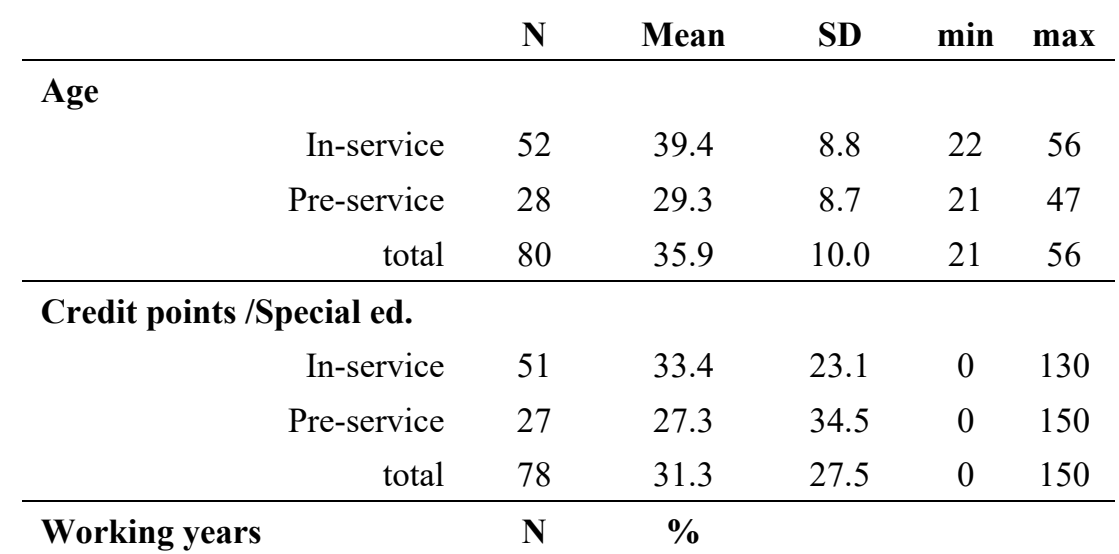

In-service

$\begin{array}{rrr}>5 & 12 & 20.7 \\ 5-10 & 19 & 32.8 \\ 10-20 & 16 & 27.6 \\ <20 & 11 & 18.9 \\ \text { total } & 58 & 100\end{array}$

Pre-service

\begin{tabular}{|c|c|c|c|}
\hline & $>5$ & 23 & 79.3 \\
\hline & $5-10$ & 4 & 13.7 \\
\hline & $10-20$ & 2 & 7 \\
\hline & $<20$ & 0 & 0 \\
\hline & total & 29 & 100 \\
\hline Gender & & $\mathbf{N}$ & $\%$ \\
\hline & & & \\
\hline & male & 9 & 15.5 \\
\hline & female & 49 & 84.5 \\
\hline & total & 58 & 100 \\
\hline & & & \\
\hline & male & 2 & 6.9 \\
\hline & female & 27 & 93.1 \\
\hline & total & 29 & 100 \\
\hline
\end{tabular}

Data were collected with online questionnaires on pre- and in-service teachers' background characteristics and their self-perceived competence in dealing with children with diverse needs and backgrounds. Participants completed a background questionnaire consisting of age, gender, educational information and working experience related questions. Well-being was assessed using surveys of engagement (UWES-S) and burnout (MBI-SS), and sense of belonging was assessed using the Psychological Sense of School Membership instrument. 


\section{Measures}

\section{Study engagement}

Study engagement was measured using a Schoolwork Engagement Scale developed by Salmela-Aro and Upadyaya (2012), originally adapted from the Utrecht Work Engagement Scale (UWES) by Schaufeli et al. (2002). The instrument measures student engagement characterized by vigour ('I was full of energy when studying'), dedication ('I found my study useful and meaningful'), and absorption ('I forgot everything around me when studying'). Questions were answered on a 7 -point scale $(1=$ totally disagree, $7=$ totally agree $)$. The Cronbach's alpha for this scale was .95. In the analysis, the sum variable of total study engagement was used. The cut-off scores presented in the UWES manual were used to determine low, moderate and high levels of study engagement.

\section{Burnout}

Study burnout was measured using a School Burnout Inventory developed by Salmela-Aro, Näätänen, and Upadyaya (see Salmela-Aro and Näätänen 2005; Salmela-Aro and Upadyaya 2009). In this study, the inventory was modified to fit the university context better. The SBI includes 9 items measuring a three-dimensional structure of burnout: 1) Exhaustion: 'I feel overwhelmed by my studies'); 2) Cynicism: 'I feel lack of motivation for my studies and often think of giving up'; 3) Sense of inadequacy: 'I often feel inadequate in my studies'. The answers were rated on a 6 -point Likert scale ( $1=$ strongly disagree to $6=$ strongly agree). The sum variable of total burnout was used in later analyses. Cut-off scores presented in the MBI manual were used to determine low, moderate and high levels of burnout. The Cronbach's alpha for burnout scale was .88 .

\section{Sense of belonging}

The student teachers' feelings of belonging were rated on a five-item scale (ranging from 1, 'not at all true', to 5, 'completely true'), thereby measuring the participants' sense of belonging to the university community and their feelings of being supported and accepted by their peers and university faculty. University belonging was assessed utilizing the 18 -item Psychological School Membership scale (Goodenow 1993), which was modified and translated into Finnish for purposes of this study (see e.g. Niemi and Hotulainen 2015). The scale included items that were about feeling accepted and included in the university (e.g. 'I 
feel like a real part of this university') and feeling supported and respected by the teaching staff (e.g. 'Teachers at this university respect me', 'The teaching staff is interested in me') as examples. Cronbach's alpha for the scale was .86 .

\section{Self-perceived competence in working with children with diverse needs}

Further, we asked participants to identify their self-perceived competence. We focused solely on pre- and in-service teachers' self-perceived and reported competence in working with children with diverse needs and backgrounds. In the survey we included specific types of needs and backgrounds as follows:

1. children with disabilities

2. children who had experienced trauma

3. children with a minority religious family background

4. children from LGBT families

5. children with parents who abuse alcohol and/or drugs

6. children with serious health problems

Participants were asked to identify whether they felt competent to work with children from each of the groups named. Answers were rated on a 5-point Likert scale ( $1=$ not competent at all to 5=Highly competent). The Cronbach's alpha for the self-perceived competence scale was .75 .

\section{Analysis}

The survey data consisted of close-ended questions about student teachers' well-being, their sense of belonging, competence and perceptions about teacher education in preparing student teachers to work with children having diverse needs. The Likert-type survey data were analysed with quantitative methods. Descriptive statistics for study variables were distinguished. Study engagement, burnout and sense of belonging did not follow normal distribution, and therefore non-parametric tests were used. To analyse the associations between variables, we used bivariate correlations with Spearman's correlation coefficient. Differences in study variables between in-service and pre-service teachers were calculated using the Mann-Whitney U-test. In the case of variables with more than two groups, the 
Kruskall-Wallis test was used. Effect sizes for the comparisons were calculated by dividing the U statistic from the Mann-Whitney test by the product of the two sample sizes (PS $=\mathrm{U} /$ $(\mathrm{n} 1 \times \mathrm{n} 2)$. Data were analysed with IBM SPSS statistics version 25 .

\section{Results}

Firstly, descriptive statistics for study engagement and burnout, sense of belonging (SEBE) and competence were distinguished. The results are presented in Table 2.

Table 2. Descriptive statistics for wellbeing, sense of belonging and self-perceived competence and comparisons between in- and pre-service teachers.

\begin{tabular}{|c|c|c|c|c|c|c|c|c|c|}
\hline & $\mathbf{N}$ & $\mathbf{M}$ & Sd & Median & $\min$ & $\max$ & $\mathbf{U}$ & Sig. & PS \\
\hline Burnout & & & & & & & 555 & 0.017 & 0.35 \\
\hline In-service & 57 & 2 & 0.7 & 2 & 1 & 3.3 & & & \\
\hline Pre-service & 29 & 2.6 & 1.1 & 2.4 & 1 & 4.7 & & & \\
\hline total & 86 & 2.2 & 0.9 & 2.1 & 1 & 4.7 & & & \\
\hline Engagement & & & & & & & 570 & 0.025 & 0.34 \\
\hline In-service & 57 & 5 & 0.8 & 5 & 2.7 & 6 & & & \\
\hline Pre-service & 29 & 4.5 & 0.9 & 4.2 & 2.8 & 6 & & & \\
\hline total & 86 & 4.8 & 0.9 & 4.8 & 2.7 & 6 & & & \\
\hline Sense of belonging & & & & & & & 215.5 & $<.001$ & 0.13 \\
\hline In-service & 57 & 2.5 & 0.6 & 2.4 & 1.5 & 3.7 & & & \\
\hline Pre-service & 29 & 3.4 & 0.5 & 3.6 & 1.6 & 4 & & & \\
\hline total & 86 & 2.8 & 0.7 & 2.8 & 1.5 & 4 & & & \\
\hline Overall competence & & & & & & & 802.5 & 0.83 & ns. \\
\hline In-service & 58 & 3.2 & 0.6 & 3.3 & 1.9 & 4.7 & & & \\
\hline Pre-service & 29 & 3.2 & 0.7 & 3.1 & 2.1 & 5 & & & \\
\hline total & 87 & 3.2 & 0.6 & 3.3 & 1.9 & 5 & & & \\
\hline
\end{tabular}

Notes: U=Mann Whitney U-test,Effect size: PS $=\mathrm{U} /(\mathrm{n} 1 \times \mathrm{n} 2)$

On average, pre- and in-service teachers demonstrated high levels of engagement and mainly low or moderate levels of burnout. In general, student teachers felt most competent in working with children from LGBT families and were less well prepared to work with children having severe disabilities. Pre-service teachers showed more SEBE than in-service teachers. 
Research objective 1: Associations between pre- and in-service teachers study well-being, sense of belonging and self-perceived competence

To answer Study Question 1, several correlation analyses (Spearman's correlation coefficient) were conducted, and the results are presented in Table 3. We could not find any correlations between sense of belonging and self-perceived competence, but these were associated with both burnout and study engagement. Furthermore, well-being variables correlated with several diverse needs categories in self-perceived competence.

Table 3. Correlations between background characteristics, wellbeing, sense of belonging and self-perceived competence. 


\begin{tabular}{|c|c|c|c|c|c|c|c|c|c|c|c|c|c|c|c|c|}
\hline \multicolumn{2}{|c|}{ Correlations } & 1 & 2 & 3 & 4 & 5 & 6 & 7 & 8 & 9 & 10 & 11 & 12 & 13 & 14 & 15 \\
\hline \multirow{15}{*}{$\begin{array}{l}\text { Spearman's } \\
\text { rho }\end{array}$} & 1 Gender & 1.00 & & & & & & & & & & & & & & \\
\hline & 2Age & -0.15 & 1.00 & & & & & & & & & & & & & \\
\hline & 3Program & 0.04 & $-.393^{* *}$ & 1.00 & & & & & & & & & & & & \\
\hline & 4WorkExperience & -0.13 & $.784^{* *}$ & $-.460^{* *}$ & 1.00 & & & & & & & & & & & \\
\hline & 5CPs in SpecialEd & -0.15 & $.364^{* *}$ & $-.323^{* *}$ & $.327^{* *}$ & 1.00 & & & & & & & & & & \\
\hline & 6Engagement & 0.10 & $.436^{* *}$ & -0.21 & $.456^{* *}$ & 0.10 & 1.00 & & & & & & & & & \\
\hline & 7Burnout & -0.04 & $-.404^{* *}$ & 0.08 & $-.360^{* *}$ & -0.09 & $-.606^{* *}$ & 1.00 & & & & & & & & \\
\hline & 8SenseofB & $.217^{*}$ & $-.385^{* *}$ & $.370^{* *}$ & $-.401^{* *}$ & -0.22 & -0.13 & 0.18 & 1.00 & & & & & & & \\
\hline & 9Competence & -0.06 & $.238^{*}$ & 0.09 & $.290^{* *}$ & 0.19 & $.289^{* *}$ & $-.232^{*}$ & 0.01 & 1.00 & & & & & & \\
\hline & 10Disab & 0.05 & 0.11 & -0.01 & 0.07 & 0.23 & $.259^{*}$ & -0.17 & 0.13 & $.433^{* *}$ & 1.00 & & & & & \\
\hline & 11Trauma & $-.227^{*}$ & $.295^{* *}$ & 0.00 & $.380^{* *}$ & 0.15 & $.272^{*}$ & -0.12 & -0.11 & $.692^{* *}$ & 0.15 & 1.00 & & & & \\
\hline & 12Religious & 0.06 & 0.16 & -0.02 & $.220^{*}$ & -0.01 & $.233^{*}$ & -0.14 & 0.09 & $.617^{* *}$ & 0.04 & $.437^{* *}$ & 1.00 & & & \\
\hline & 13LGBT & 0.03 & -0.19 & 0.20 & -0.16 & 0.15 & -0.05 & 0.08 & 0.08 & $.542^{* *}$ & 0.09 & 0.10 & $.270^{*}$ & 1.00 & & \\
\hline & 14Drugs & -0.19 & $.243^{*}$ & -0.02 & $.366^{* *}$ & 0.20 & 0.20 & -0.21 & -0.01 & $.744^{* *}$ & $.214^{*}$ & $.515^{* *}$ & $.358^{* *}$ & $.385^{* *}$ & 1.00 & \\
\hline & 15 Health & -0.14 & $.308^{* *}$ & 0.12 & $.319^{* *}$ & 0.06 & 0.15 & -0.19 & -0.04 & $.670^{* *}$ & $.214^{*}$ & $.574^{* *}$ & $.396^{* *}$ & 0.16 & $.493^{* *}$ & 1.00 \\
\hline
\end{tabular}

Notes: ${ }^{*} \mathrm{p}<.05, * * \mathrm{p}<.01$ 
As we observed that sense of belonging was not associated with competence $(p>.05)$ nor with study engagement and burnout ( $p>.05)$, there was no need for further analysis. Study engagement and burnout were associated with competence, so we examined their relations to competence in greater depth. Participants were categorized according to their level of engagement and burnout as either low, moderate or high. However, in comparisons, participants in different engagement and burnout groups did not differ significantly in their self-perceived competence (Table 4).

Table 4. Self-perceived competence in low, moderate and high study burnout and study engagement groups

\begin{tabular}{|c|c|c|c|c|c|c|c|c|c|c|}
\hline \multicolumn{2}{|c|}{ Self-perceived competence } & $\mathrm{N}$ & M & $\mathrm{Sd}$ & Median & Min & Max & $\mathrm{H}$ & Sig. & PS \\
\hline \multirow[t]{5}{*}{ Burnout } & & & & & & & & 4.94 & $\mathrm{p}=.085$ & $\mathrm{~ns}$ \\
\hline & Low & 25 & 3.4 & 0.69 & 3.4 & 2 & 5 & & & \\
\hline & Moderate & 53 & 3.2 & 0.58 & 3.14 & 1.86 & 4.71 & & & \\
\hline & High & 7 & 2.9 & 0.65 & 2.7 & 2.29 & 4 & & & \\
\hline & Total & 85 & & & & & & & & \\
\hline \multirow[t]{5}{*}{ Engagement } & & & & & & & & 5.97 & $\mathrm{p}=.057$ & ns \\
\hline & Low & 6 & 2.8 & 0.49 & 2.9 & 2.29 & 3.43 & & & \\
\hline & Moderate & 24 & 3.1 & 0.61 & 3.07 & 2 & 4.14 & & & \\
\hline & High & 55 & 3.3 & 0.63 & 3.3 & 1.86 & 5 & & & \\
\hline & Total & 85 & & & & & & & & \\
\hline
\end{tabular}

We further wanted to investigate how background variables such as age, gender and working experience are linked to well-being, sense of belonging and competence. These results are presented in Table 5. 
Table 5. Differences in study variables according to age, gender and working experience

\begin{tabular}{|c|c|c|c|c|c|c|c|c|}
\hline & Age & & & & & $\mathbf{H}$ & Sig & Difference \\
\hline & 1) $<30$ & 2)30-40 & 3) $40-50$ & 4) $>50$ & & & & \\
\hline OverallComp & $3.1 \pm 0.76$ & $3.15 \pm 0.45$ & $3.28+0.68$ & $3.55 \pm 0.61$ & & 4.43 & .22 & \\
\hline Competence/Disability & $2.12 \pm 1.1$ & $1.91 \pm .0 .97$ & $2.33 \pm 1.5$ & $2.14 \pm 0.48$ & & 1.58 & .6 & \\
\hline Competence/Trauma & $3.24 \pm 1.17$ & $3.27 \pm 0.88$ & $3.58 \pm 1.1$ & $3.71 \pm 0.95$ & & 8.04 & .045 & $1,2<4$ \\
\hline Competence/Religious & $3.37 \pm 1.15$ & $3.45 \pm 1.01$ & $3.42 \pm 1.21$ & $3.43 \pm 1.27$ & & 2.64 & .45 & \\
\hline Competence/LGBT & $2.64 \pm 1.19$ & $3 \pm 0.69$ & $3.08 \pm 0.93$ & $3.86 \pm 0.69$ & & 5.8 & .12 & \\
\hline Comptence/Drugs & $4.68 \pm 0.56$ & $4.09 \pm 1.07$ & $4.21 \pm 0.98$ & $4.29 \pm 0.76$ & & 6.71 & .08 & \\
\hline Competence/Health & $3.32 \pm 1.11$ & $3.12 \pm 0.66$ & $3.54 \pm 0.93$ & $4.14 \pm 0.69$ & & 9.22 & .03 & $1,2,3<4$ \\
\hline Study Bumout & $2.8+0.97$ & $2 \pm 0.94$ & $1.9 \pm .0 .68$ & $1.7 \pm 0.54$ & & 14.9 & $<.001$ & $1>2,3,4$ \\
\hline Study Engagement & $4.2 \pm 0.86$ & $5.09 \pm 0.56$ & $5.09 \pm 0.79$ & $5.24 \pm 0.75$ & & 19.7 & .001 & $1>2,3,4$ \\
\hline \multirow[t]{3}{*}{ Sense of belonging } & $3.32 \pm 0.5$ & $2.6 \pm 0.73$ & $2.72 \pm 0.77$ & $2.33 \pm 0.44$ & & 16.74 & .001 & $1<2,3,4$ \\
\hline & Gende & & & & & $\mathbf{U}$ & Sig & \\
\hline & Male & Female & & & & & & \\
\hline OverallComp & $3.3 \pm 0.71$ & $3.23 \pm 0.64$ & & & & 380 & .56 & \\
\hline Competence/Disability & $1.9 \pm 0.57$ & $2.21 \pm 1.14$ & & & & 380 & .66 & \\
\hline Competence/Trauma & $3.1 \pm 1.1$ & $2.56 \pm 0.93$ & & & & 259.5 & .036 & \\
\hline Competence/Religious & $3.1 \pm 1.23$ & $3.45 \pm 0.96$ & & & & 371.5 & .58 & \\
\hline Competence/LGBT & $4.1 \pm 0.67$ & $4.35 \pm 0.95$ & & & & 391.5 & .76 & \\
\hline Comptence/Drugs & $4 \pm 0.67$ & $3.55 \pm 0.95$ & & & & 281.5 & .073 & \\
\hline Competence/Health & $3.3 \pm 0.95$ & $3.03 \pm 0.1$ & & & & 317 & .2 & \\
\hline Study Bumout & $2.3 \pm 0.99$ & $2.19 \pm 0.91$ & & & & 349.5 & .73 & \\
\hline Study Engagement & $4.6 \pm 0.71$ & $4.83 \pm 0.88$ & & & & 308.5 & .36 & \\
\hline \multirow[t]{3}{*}{ Sense of belonging } & $2.37 \pm 0.51$ & $2.87 \pm 0.75$ & & & & 229 & .046 & \\
\hline & \multicolumn{5}{|c|}{ Working experience (yrs) } & $\mathbf{H}$ & Sig & \\
\hline & 1)<5 & 2) $5-10$ & 3) $10-20$ & 4) $20-30$ & 5) $>30$ & & & \\
\hline OverallComp & $3.05 \pm 0.76$ & $3.08 \pm 0.65$ & $3.21 \pm 0.54$ & $3.5 \pm 0.52$ & $3.39 \pm 0.72$ & 7.26 & .12 & \\
\hline Competence/Disability & $2 \pm 1.24$ & $2.29 \pm 1.06$ & $2.09 \pm 1.12$ & $2.33 \pm 1.24$ & $2.1 \pm 0.74$ & 1.75 & .78 & \\
\hline Competence/Trauma & $2.43 \pm 1.28$ & $2.14 \pm 0.91$ & $2.64 \pm 0.66$ & $3.06 \pm 0.87$ & $3.10 \pm 0.89$ & 14.65 & .005 & $2<3,4,5$ \\
\hline Competence/Religious & $3.14 \pm 1.17$ & $3.19 \pm 1.08$ & $3.41 \pm 0.86$ & $3.72 \pm 1.02$ & $3.7 \pm 0.82$ & 4.23 & .38 & \\
\hline Competence/LGBT & $4.57 \pm 0.65$ & $4.48 \pm 0.68$ & $4.23 \pm 1.07$ & $4.1 \pm 0.86$ & 4. $1 \pm 1.2$ & 2.51 & .64 & \\
\hline Comptence/Drugs & $3.14 \pm 1.03$ & $3.29 \pm 1.01$ & $3.77 \pm 0.87$ & $3.83 \pm 0.79$ & 4. $1 \pm 0.57$ & 12.12 & .016 & $1<4,5$ \\
\hline Competence/Health & $2.64 \pm 0.93$ & $2.76 \pm 1.18$ & $3.14 \pm 0.89$ & $3.39 \pm 0.85$ & $3.5 \pm 0.85$ & 8.78 & .067 & \\
\hline Study Bumout & $2.75 \pm 1.03$ & $2.56 \pm 0.95$ & $1.92 \pm 0.79$ & $2.01 \pm 0.74$ & $1.69 \pm 0.66$ & 13.26 & .01 & $1>3,4,5 \& 2>3,5$ \\
\hline Study Engagement & $4.2 \pm 0.82$ & $4.47 \pm 0.86$ & $4.96 \pm 0.88$ & $5.18 \pm 0.61$ & $5.32 \pm 0.66$ & 17.83 & .001 & $1<3,4,5 \& 2,4,5$ \\
\hline Sense of belonging & $3.34 \pm 0.57$ & $3.05 \pm 0.68$ & $2.63 \pm 0.71$ & $2.52 \pm 0.78$ & $2.48 \pm 0.6$ & 14.56 & .006 & $1>3,4,5 \& 2>3,4$ \\
\hline
\end{tabular}

\section{Research Objective 2: Differences between pre- and in-service teachers}

Our second aim was to determine differences between pre-service and in-service teachers in study engagement, burnout and sense of belonging. Additionally, we tested whether preservice and in-service teachers differ in their self-perceived competence in dealing with children with diverse needs. Mann-Whitney U-tests were run, and the results of the tests are presented in Table 2. We found that in-service teachers demonstrated fewer symptoms of burnout and higher engagement than pre-service teachers. However, pre-service teachers 
showed stronger sense of belonging compared to in-service teachers. In-service and preservice teachers did not differ in their self-perceived competence in working with children with diverse needs and backgrounds ( $\mathrm{p}>.05)$.

\section{Discussion}

This study examined pre-service and in-service teachers' well-being, sense of belonging and self-perceived competence in dealing with children with diverse needs. Our study contributed to the research literature in several ways. The aim was to learn more about the factors that are associated with pre- and in-service teachers' self-perceived competence and the extent to which well-being and belonging to a university community potentially are linked to teachers' readiness to cater to and meet the diverse needs of children from various backgrounds.

Although our study could not confirm all the connections presented in the theoretical model (Figure 1), which was intended to illustrate the complex relationships among the variables, it does shed light on important research topics that should be studied further and utilized in teacher education. Our study is novel in suggesting that well-being and competence in dealing with children with diverse needs are associated factors among in-service and preservice teachers. Although with our cross-sectional study design we were unable to demonstrate the direction of these associations between key variables and how they emerge, we did discover encouraging findings, which are discussed in some detail below.

Our findings relating to pre- and in-service teachers' well-being are in line with previous literature on teacher professionalism, which has demonstrated that better well-being is linked to better performance (Hakanen, Bakker, and Schaufeli 2006; Bakker and Bal 2010). Still more interesting is that comparisons according to age group or working experience did not confirm any significant differences in overall self-perceived competence among these teachers. However, differences were found self-perceived competence in various diverse needs categories among older and more experienced participants, as these teachers were more competent in dealing with children with severe health problems or who were traumatized or had experienced family drug abuse. Older participants may already have life experiences that can contribute positively to their self-experienced competence.

We found that only age and working experience were associated with self-perceived competence, whereas credit points in special education did not have any link to self-perceived 
competence. Similarly, no differences in self-perceived competence between pre-service and in-service teachers were found. We believe that skills and knowledge in working with children with diverse needs and backgrounds are acquired during studies, in working life and in everyday life. Teacher education and training provide an important foundation for those skills and for basic understanding about diverse learners, but overall, competence appears to be shaped throughout one's career, for example, in collaboration with colleagues (e.g. Heikkinen, Jokinen, and Tynjala 2012; Lofthouse and Thomas 2017).

Contrary to our expectations sense of belonging was not associated with well-being. Sense of belonging did not correlate with burnout nor were associations with engagement found. This is a rather interesting finding as previous studies have demonstrated associations between sense of belonging and emotional disturbances such as depression or anxiety (e.g. Juvonen 2006; Pesonen, Kontu and Pirttimaa 2015; Pesonen et al. 2016). One explanation may be that the participants in our study were generally highly engaged and showed rather few symptoms of burnout. This, however, is a positive result, and shows how motivated and engaged preand in-service teachers are in their studies, especially in-service teachers.

Similarly, lack of associations between the well-being variables and sense of belonging can be due to the characteristics of our participant groups. We found that pre-service and inservice teachers differed in their experience of sense of belonging, with pre-service teachers demonstrating higher levels. This can be explained by the fact that full-time degree students (e.g. pre-service teachers) take part more frequently in university community activities (e.g. student activities and clubs), which leads them to feel a sense of belonging (Freeman, Anderman, and Jensen 2007).

Furthermore, participation and interaction with fellow degree students can be explained by students' developmental status as late adolescents, whereas in-service teachers are older with more life experience and therefore may feel more sense of belonging in their present work community than they did in their study contexts (see e.g. Skaalvik and Skaalvik, 2011). The instrument used in the current study was formulated to assess sense of belonging particularly in a study context, and therefore our results cannot give any further explanations for the participants overall sense of belonging. Nevertheless, the instrument gives us an estimate of the pre- and in-service teachers' feelings of togetherness during their special education teacher studies. 
Teacher education has an important role to play in providing qualifying teachers the kinds of attitudes and values that create a school climate that welcomes all students to participate and feel accepted. The most recent report by a steering group of the Finnish Ministry of Education raised concerns about in-service teacher competencies and qualifications (Finnish Ministry of Education and Culture 2017). Specifically, there is a lack of teachers with special education qualifications for working with students with disabilities (e.g. significant learning and developmental disabilities). Also relatively few teachers have competence in educating children with severe health problems (e.g. mental health illnesses) (Kokko et al. 2014; Kontu et al. 2017). The report recommended more in-depth in-service training for teachers as well as broader integration of special educational content into teacher education (Finnish Ministry of Education and Culture 2017). This is in line with our findings, which demonstrate that preand in-service teachers are less competent in dealing with children with severe disabilities and children who are traumatized.

\section{Limitations and future directions}

There are several limitations to this study that should be taken into account when interpreting the results. Our sample size was fairly small; a larger size would have been needed for more explanatory power. Additionally, due to the heterogeneous participant groups the results can be biased. In our sample, we had both pre-service and in-service teachers from different backgrounds and with different teaching experience. For example, in-service teachers from different school levels were grouped together because our small sample size did not allow us to analyse them separately. Such grouping would definitely be worth re-considering in future studies with a larger sample size. The scale we used in measuring pre- and in-service teachers' self-perceived competence could not capture the multidimensional nature of competence (including e.g. self-efficacy and pedagogical knowledge); instead, it offered simply a glimpse into a self-experienced and reported ability. Although our aim was to identify the participants' competence to work with children from the six different groups of diverse needs by utilizing a five-point Likert scale, the scale might not be the most convincing way to measure this concept. More objective methods such as classroom observations during teacher training could be useful in detecting pre- and in-service teachers' core skills in working with children with diverse needs and backgrounds. Additionally, collecting data from multiple measurement points during teacher training perhaps could give 
a broader perspective and valid information regarding the developmental nature of selfreported competence.

In the next phase, our aim is to study and compare the underpinnings of well-being, sense of belonging and self-perceived competence with multiple methodologies in order to attain a broader understanding of the phenomenon. A mixed-methods approach will be utilized in the next stage of the research. We will collect interview data to probe more deeply into the data patterns. With various data sources, we will not only gain a broader understanding of the phenomenon, but also will be able to develop the theoretical model further. For example, with more data sources and a longitudinal study design, it might be possible to explore the causal effects between the study variables.

\section{Conclusion}

Our study is timely, given that the increase in inclusive educational arrangements requires that teachers today have the abilities and skills to identify and use appropriate strategies to support children with various needs and backgrounds (Engelbrecht and Savolainen, 2017; Savolainen et al. 2012). For example, in Finland, supporting students with diverse educational needs is mandatory, as stated in the educational system's three-tiered support model (see the Basic Education Act 642/2010; Basic Education Act 628/1998). Much emphasis has been placed on the educational arrangements for children with various types of support needs in order to reduce segregated schooling (Finnish National Board of Education 2014). Instead, children with and without diverse needs are being placed in the same classrooms, the aim being to provide them with support in their present settings (Thuneberg et al. 2013). The inclusive education settings have appeared to challenge teachers' professional competence and coping skills, especially by students having moderate or significant and multiple disabilities or severe mental health problems (Ojala 2017; Kontu et al. 2017). Our study also suggests a similar trend in accordance with these findings, as preand in-service teachers reported less self-perceived competence in these areas. Further studies are unquestionably needed in order to confirm these findings and to gain research-based content for teachers training programs.

However, to mention a positive notion in our data, pre- and in-service teachers appear to be highly engaged in their studies. This might reflect the fact that teacher education succeeds in offering qualifying teachers a basis for developing their professional identities. In Finland, 
teaching is a highly respected profession, and the Finnish educational system is characterized by trust in the teachers (Pesonen et al. 2015; Sahlberg 2010). This might explain why teacher preparation programmes attract engaged candidates, as seems specifically to be the case among in-service teachers obtaining special education teacher qualifications.

The phenomenon under investigation in the current study appears to be multidimensional and its various factors are challenging to verify with the present data. We consider it is necessary to collect further interview data using a sequential mixed-methods approach in order to understand better the complexity of the theoretical model, and thereby re-evaluate the potential functionality of the model, for example. Overall, further studies focusing on the underpinnings of the sense of belonging, well-being and self-perceived competence in working with children with diverse needs are unquestionably needed in order to develop an understanding of the associations among these factors. 


\section{References}

Ahtiainen, R. 2017. Shades of change in Fullan's and Hargreaves's models: Theoretical change perspectives regarding Finnish special education reform. Helsinki: University of Helsinki

Basic Education Act. (628/1998). Finnish Ministry of Education and Culture.

Basic Education Act. (642/2010). Finnish Ministry of Culture and Education. Accessed April 11, 2018. https://www.finlex.fi/en/laki/kaannokset/1998/en19980628.pdf

Bakker, A. B., and P. M. Bal. 2010. "Weekly work engagement and performance: A study among starting teachers." Journal of Occupational and Organizational Psychology 1: 189206.

Bakker, A. B., E. Demerouti, and W. Verbeke. 2004. "Using the job demands-resources model to predict burnout and performance.”.Human Resource Management 43(1): 83-104.

Baumeister, R.F., and M.R. Leary. 1995. "The need to belong: Desire for interpersonal attachments as a fundamental human motivation." Psychological Bulletin 117: 497-529.

Brouwers, A., and W. Tomic. 2000. "A longitudinal study of teacher burnout and perceived self-efficacy in classroom management." Teaching and Teacher education 16(2): 239-253.

Buchanan, J. 2010. "May I be excused? Why teachers leave the profession." Asia Pacific Journal of Education 30: 199-211.

Campbell, J., L. Gilmore, and M. Cuskelly. 2003. "Changing student teachers' attitudes towards disability and inclusion." Journal of Intellectual and Developmental Disability 28(4): 369-379.

Demerouti, E., F. Nachreiner, A. B., Bakker, and, W. B. Schaufeli. 2001. "The job demandsresources model of burnout." Journal of Applied Psychology 86(3): 499-512.

Engelbrecht, P. and H. Savolainen. 2017. "A mixed-methods approach to developing an understanding of teachers' attitudes and their enactment of inclusive education.".European Journal of Special Needs Education . DOI:10.1080/08856257.2017.1410327

Estola, E., R. Erkkilä, and L. Syrjälä. 2003. "A Moral Voice of Vocation in Teachers' Narratives." Teachers and Teaching: theory and practice 9 (3): 239-256.

Ferguson, D. L. 2008. " International trends in inclusive education: the continuing challenge teach each one and everyone." European Journal of Special Needs Education 23: 109-120. 
Finnish Ministry of Education and Culture. 2017. Vaativa erityinen tuki esi-ja perusopetuksessa. Kehittämisryhmän loppuraportti. [Significant support needs in pre- and basic education. The final report by the development group]. Opetus- ja kulttuuriministeriön julkaisuja 2017:34: Helsinki.

Finnish National Board of Education. 2014. National curriculum for basic education. Finnish ministry of education. Next Print Oy: Helsinki.

Freeman, T. M., L. H. Andermand, and J. M. Jensen. 2010. "Sense of belonging in college freshmen at the classroom and campus levels." The Journal of Experimental Education 75(3): 203-220.

Freeman, T.M., L. H. Anderman, and J. M. Jensen. 2007. "Sense of Belonging in College Freshmen at the Classroom and Campus Levels." The Journal of Experimental Education 75(3) :203-220. DOI: 10.3200/JEXE.75.3.203-220.

Goodenow, C. 1993. "The psychological sense of school membership among adolescents: Scale development and educational correlates." Psychology in the Schools 30: 79-90.

Hagerty, B.M.K., J. Lynch-Sauer, K. L., Patusky, M. Bouwsema, and P. Collier. 1992." Sense of belonging: A vital mental health concept." Psychiatric Nursing 3: 172-177.

Heikkinen, H.L.T., H. Jokinen, and P. Tynjala. 2012. "Chapter 1, Teacher education and development as lifelong and lifewide learning.” In: H.L.T. Heikkinen, H. Jokinen, and P. Tynjala, eds. Peer-group mentoring for teacher development. London: Routledge.

Hakanen, J. J., A. B. Bakker, and W. B. Schaufeli. 2006. "Burnout and work engagement among teachers." Journal of School Psychology 43: 495-513.

Hakanen, J. 2009. Työn imua, tuottavuutta ja kukoistavia työpaikkoja? Kohti laadukasta työelämää. [Work engagement, productivity, and flourishing workplaces? Towards highquality working life]. Report of the Finnish Institute of Occupational Health, Helsinki.

Hoffman, M.B., J.R. Richmond, J.A. Morrow, and K. Salomone. 2002. "Investigating "sense of belonging" in First-Year college students". Journal of College Student Retention 4 (3): 227-256.

Juvonen, J. 2006. "Sense of belonging, social bonds, and school functioning". In P. Alexander and P. Winne, eds., Handbook of educational psychology (2nd ed.), 655-674. New York: Macmillan. 
Klassen, R. M. and M. M. Chiu. 2010. "Effects on teachers' self-efficacy and job satisfaction: Teacher gender, years of experience, and job stress. " Journal of educational Psychology 102 (3): 741 .

Kontu, E, T. Ojala, H. Pesonen, T. Kokko, and R. Pirttimaa. 2017. "Vaativan erityisen tuen käsite ja tutkimustuloksia" (VETURI-hanke 2011-2015). [The concept of significant support needs and research results]. in Vaativa erityinen tuki esi- ja perusopetuksessa.

Kehittämisryhmän loppuraportti. [Significant support needs in pre- and basic education. The final report by the development group]. Opetus- ja kulttuuriministeriön julkaisuja 2017:34: Helsinki.

Lauermann, F. and J. König. 2016. "Teachers' professional competence and wellbeing: Understanding the links between general pedagogical knowledge, self-efficacy and burnout." Learning and Instruction 45, 9-19.

Lofthouse, R., and U. Thomas. 2017. "Concerning collaboration: teachers' perspectives on working in partnerships to develop teaching practices." Professional Development in Education 43 (1): 36-56. DOI: 10.1080/19415257.2015.1053570

Ma, X. 2003. "Sense of belonging to school: can schools make a difference." The Journal of Educational Research 96 (6): 340-349.

Montgomery, C. and A. A. Rupp. 2005. "A meta-analysis for exploring the diverse causes and effects of stress in teachers." Canadian Journal of Education/Revue canadienne de l'éducation 458-486.

Murray, C., and M. T. Greenberg. 2000. "Children's Relationship with Teachers and Bonds with School An Investigation of Patterns and Correlates in Middle Childhood." Journal of School Psychology 38 (5):423-445 DOI: 10.1016/S0022-4405(00)00034-0

Nislin, M., M. Paananen, L.Repo, N. Sajaniemi, and M., Sims 2015. Working with children with special needs in Finnish kindergartens: Professionals and/or specialists?South African Journal of Childhood Education, 5(3), DOI: 10.4102/sajce.v5i3.368

Nislin, M. 2016. Nerve-wracking or rewarding? A multidisciplinary approach to investigating work-related well-being, stress regulation and quality of pedagogical work among early childhood professionals. Doctoral dissertation. Yliopistopaino Unigrafia: Helsinki.

Ojala, T. 2017. "When pupils have emotional and behavioral disorders in comprehensive school - teachers experiences.” Doctoral dissertation. Jyväskylä University Printing House: Jyväskylä. 
Onnismaa, E. L., L.,Tahkokallio, and M. Kalliala. 2015. "From university to working life: an analysis of field-based studies in early childhood teacher education and recently graduated kindergarten teachers' transition to work." Early Years 35 (2): 197-210.

Paju, B., L. Räty, R. Pirttimaa and Kontu E. 2015. "The school staff's perception of their ability to teach special educational needs pupils in inclusive settings in Finland."

International Journal of Inclusive Education DOI:10.1080/13603116.2015.1074731

Pesonen, H., T. Itkonen, M. Jahnukainen, E. Kontu, T. Kokko, and R. Pirttimaa. 2015.'The implementation of new special education legislation in Finland." Educational Policy 29 (1): 162-178.

Pesonen, H, E. Kontu, and R. Pirttimaa. 2015. "Sense of belonging and life transitions for two females with autism spectrum disorder in Finland." The Journal of International Special Needs Education 18 (2): 73-86. DOI: 10.9782/2159-4341-18.2.73

Pesonen, H. 2016. Sense of belonging for students with intensive special education needs: An exploration of students' belonging and teachers' role in implementing support. Doctoral dissertation. Yliopistopaino Unigrafia: Helsinki.

Pesonen, H, E. Kontu, M. Saarinen, and R. Pirttimaa. 2016: "Conceptions associated with sense of belonging in different school placements for Finnish pupils with special education needs." European Journal of Special Needs Education 31 (1): 59-75. DOI: 10.1080/08856257.2015.1087138

Prince, E.J., and J. Hadwin. 2013. "The role of a sense of school belonging in understanding the effectiveness of inclusion of children with special needs." International Journal of Inclusive Education 17 (3): 238-262.

Rantala, T., and K. Määttä. 2011. "Ten thesis of the joy of learning at primary schools." Early Child Development and Care iFirst. doi: 10.1090/03004430.2010.545124.

Sahlberg, P. 2010. "Rethinking accountability in a knowledge society." Journal of Educational Change 1, 45-61.

Salanova, M., W. B. Schaufeli, D. Xanthopoulou, and A.B Bakker. 2010. "The gain spiral of resources and work engagement: Sustaining a positive worklife." Work engagement: A handbook of essential theory and research 118-131.

Salmela-Aro, K., A. Tolvanen, and J.E. Nurmi. 2009. "Achievement strategies during university studies predict early career burnout and engagement." Journal of Vocational Behavior 75(2): 162-172. 
Savolainen, H. 2009. "Responding to diversity and striving for excellence: The case of Finland.” Prospects 39, 281-292. DOI 10.1007/s11125-009-9125-y

Savolainen, H. , P. Engelbrecht, M. Nel and O. P. Malinen. 2012. 'Understanding teachers' attitudes and self-efficacy in inclusive education: implications for preservice and in-service teacher education." European Journal of Special Needs Education 27 (1): 51-68, DOI: $10.1080 / 08856257.2011 .613603$

Schaufeli, W. B., M. Salanova, V. Gonzalez-Roma, and A.B. Bakker. 2002. "The measurement of engagement and burnout: A two sample confirmatory factor analytic approach.” Journal of Happiness Studies 3, 71-92.

Schaufeli, W. B., and A.B. Bakker. 2004. " Job demands, job resources, and their relationship with burnout and engagement: A multi-sample study." Journal of Organizational Behavior, 25, 293-315.

Slaavik, E. M., and Slaavik, S. 2011. "Teacher job satisfaction and motivation to leave the teaching profession: Relations with school context, feeling of belonging, and motivational exhaustion." Teaching and teacher education 27, 1029-2038.

Thuneberg, H., M.P. Vainikainen, R. Ahtiainen, M. Lintuvuori, K. Salo, and J. Hautamäki. 2013. "Education is special for all: the Finnish support model." Belltz Juventa, Gemeinsam Leben 2, 67-78.

Vasalampi, K., K. Salmela-Aro, and J.E. Nurmi. 2009. “Adolescents' self-concordance, school engagement, and burnout predict their educational trajectories." European psychologist 14(4), 332-341.

\footnotetext{
i 'Diverse needs' refers to children with disabilities, for example.

ii "Diverse backgrounds" refers to children who are maltreated or neglected, for instance.
} 